IIUC STUDIES

ISSN 1813-7733

Vol.- 7, December 2010

(Published in December 2011) (p 9-24)

\title{
Developing Critical Thinking: A Case Study of Teaching a Hemingway Story
}

\author{
Mohd. Yasin Sharif*
}

\begin{abstract}
English Literature is generally taught at tertiary level in Bangladesh to develop the critical and analytical ability of students, so as to enable them to develop their own evaluation and assessment of texts studied in classrooms. Such assumption often proves in vain, because even tertiary level students depend more on their cognitive capacity rather than their creative ability. Thus the ability of a student to think critically seldom grows because critical thinking (ct) is a faculty which only increases with practice and concentration. This paper endeavors to explore critical thinking ability as an important aspect of pedagogy which further enables a learner to be self-confident and inspirational in using his/her acquired knowledge both in the academy as well as in real life situations. The main focus of the paper is the traditional or classical process of literature study in classroom situations we usually practice in this part of the world to develop the psychology, thought process, and maturity of a learner. Literature is thought to have the power to develop or to create curiosity in learners in finding out the critical situation of real world. Again literature is believed to be a collection of characters, reflection of real life, absurdity, and the hundreds and thousands of problems and solutions to be encountered by a learner everyday which develops the faculty in learners to adjust or overcome hurdles in real life. Thus the paper through the analysis of a popular American short story "A Clean, Well-Lighted Place" by Ernest Hemingway tries to address the problems and solutions related to the teaching/development of critical thinking ability.
\end{abstract}

\section{Introduction}

Before going to an elaborate discussion, it is useful to define the phrase "critical thinking". The term is a loaded one. "Critical thinking is the intellectually disciplined process of actively and skillfully

* Assistant Professor, Department of English Language \& Literature, IIUC. 
conceptualizing, applying, analyzing, synthesizing, and/or evaluating information gathered from, or generated by, observation, experience, reflection, reasoning, or communication, as a guide to belief and action" (Scriven \& Paul 01). It implies that the manner of assessment of any subject, content, or problem through which learners enhance the quality of their thinking by displaying their power of thinking and demonstrating intellectual standards. In short, critical thinking ability is self-directed, self-tutored, self-supervised and self- corrective thinking. It involves successful interaction and the ability to meet any kind of challenge. Kagnarith et. al (3) believe "Self-regulation (sometimes referred to as metacognition) takes on a more global significance in the critical thinking process."

In the critical thinking process learners try to find out the meaningful application of the text studied and establish a connection with a real life phenomenon to find out some moral or ethical teaching out of it. The term "critical" gives negative connection most of the time which needs to be clarified to many by interpretation. However, in society different people may have different ideologies and opinion, based on their critical perspectives of a situation. Thus critical thinking does not essentially mean agreeing to reach an authentic or genuine truth in a very diverse way. In this connection Gough (99-100) observes that "Perhaps most importantly in today's information age, thinking skills are viewed as crucial for educated persons to cope with a rapidly changing world. Many educators believe that specific knowledge will not be as important to tomorrow's workers and citizens as the ability to learn and make sense of new information"

Critical thinking is essential in the modern learning and teaching arena. Almost all educators pay much attention to teaching critical thinking for their students. The aim of all teachers is to teach critical thinking skills to enable students to detect topic in their subjects accurately, and construct and utilize various problems in exams that can test students' critical thinking skills. The aim of almost all academic instructions is to offer students approaches to comprehend and appraise themes. Beyth et al. (216) underscore this point, characterizing thinking skills as means of making good choices: "Thinking skills are necessary tools in a society characterized by rapid change, many alternatives of actions, and numerous individual and collective choices and decisions"

As the volume of academic material increases students are much more dependent on memorization than on displaying their creativity. 
Without any doubt, the elemental task of transmitting the process of proper exploration, appreciation, and estimation of all literary texts are put aside by learners. This condition greatly affects the system of learning and teaching of primary and secondary level in our country. Human beings are not born with the ability to think critically, nor do they acquire this capability naturally beyond survival-level thinking. Critical thinking is an academic ability that must be acquired.

Brumfit and Carter (234) state that "The first task must be to get people reading books for meaning and making connections between them, and outwards non-literary experiences, as a matter of personal need. They further suggest "we cannot analyze an experience we have never had, and the literary experience arises from thinking about books as meaningful, important patterning of experience, integrated with our own experience, both, direct and vicarious". Book merely amuses or provides some evidence or truth to a normal reader, but it uncovers more to a contemplative reader. Thus critical readings of a text enable readers to merge themselves with the author's attitude towards a particular issue, establishing a strong bondage between the reader and an author in the process. Critical thinking can be seen as a way of interacting with a text that enables a reader to grasp the essence of the text as well as contribute to the various aspects of the text through his or her own individual interpretation of a given situation. Thus critical reading and critical thinking is hard-wired together. It can be said that without critical reading the understanding of a text is essentially impossible. An author initiates a text and a reader culminates it. This puts us in a very problematic situation: do we really have such learners who have the ability to analyze and evaluate a text in innovative and lucrative ways?

\section{The Distinctiveness of Critical Thinkers}

Critical thinking consists of a complicated amalgamation of various skills. Critical readers or thinkers are always curious. They are always in the habit of analyzing attitudes, suppositions, and judgment and evaluating them in the light of evidence. This way they come to a new conclusion. Critical thinkers are always careful in paying heed to others and if necessary responding positively. Critical thinkers are so rational that they reject what is incorrect or unnecessary. They are good organizers who deal with ideas precisely and logically. They anticipate the consequences of an action in advance and are unique individuals having a taste of their own. They can strip a verbal argument of irrelevancies and phrase it in its essential terms. They 
habitually ask one's own views and attempt to understand both the assumptions that are critical to those views and the implications of these views. They are sensitive to the difference between the validity of a belief and the intensity with which it is held. They recognize the fallibility of one's own opinions, the probability of bias in those opinions, and the danger of weighting evidence according to personal preferences. Metacognition is a unique characteristic of a critical thinker. To be precise, "metacognition is being aware of one's thinking as one performs specific tasks and then using this awareness to control what one is doing" (Jones \& Ratcliff 642).

\section{Developing Critical Thinking:}

Literature is like a chariot which carries us from horizon to horizon. After acquiring a level of understanding of a text, readers feel like exploring more and more. This way a new aspect of the reader is developed which is solely created and mostly and uniquely understood by the readers themselves which no one before them and not even the author himself/herself had thought of. In the same way, once students are tutored to have proof in support of their arguments they cannot but bring it into practice. For example, in studying Wordsworth's 'Immortality Ode' often ordinary students find it difficult to admit to the pre-natal existence of human soul. But students who think critically grasp such an unintelligible dogma very easily and relate it masterfully, quoting from philosophers like Plato, Descartes, and Rousseau etc. to make their proof. Though sometimes such critically developed students prove to be a bit immature in their expression and interpretation yet they usually develop their critical thinking ability without submitting to the authors or poets views easily.

Critical thinking develops self-respect among learners. Thus a classroom where learners learn critical thinking develops a kind of self-estimation in them and a belief in their own point of view. A teacher can straightway teach critical thinking strategies to students during lecture by providing new and innovative facts and data. It is proved by research that critical thinking is as much a tendency of the mind as well as a "personal disposition to open-mindedness, inquisitiveness, and willingness to reconsider in light of new information" (Facione 10).

A teacher can enhance critical thinking in a learner during a lecture by periodically stopping and asking students searching and thoughtful questions about the material presented in the class, and then waiting 
for an appropriate time for them to respond. Teachers should not instantaneously answer any question if students fail to answer it, rather, students should be provided ample time to think before teachers give out their ideas. If a teacher constantly answers such questions himself/herself, students will quickly be aware of this trait and will not respond. Students should be addressed by their respective names and all should be given a chance to participate in class performance by asking questions. If learners fail to respond correctly the instructor should help them by simplifying the question and directing them through the thought process; asking what data are needed to answer the question, and advising them a bit on how the data can be utilized to respond to the question, and engaging students to apply this data in a suitable way in giving an answer.

Teachers should ask students factual questions in between lectures. Many students face a problem with factual questions because they do not pay any attention in class. These students simply do not know how to listen to a lecture and take mental or written notes, or don't know how to analyze their notes and look at the textbook in preparation for an exam. Perhaps the most basic type of critical thinking is knowing how to listen to a lecture actively rather than passively; many students don't know how to do this because they were never taught the process. That is why factual questions should be asked at the very initial stage of a lecture to compel students to be attentive and active in listening to the class lecture. However, the objective of critical thinking is to ask students questions that force them to think through a "cause and effect" or "premise and conclusion" type of argument. This strategy forces them to use the information they acquire from the class lecture to reach novel conclusions or understand a topic.

In a literary class questions must be asked to students. It is usually seen that in such classes students are mere receivers of information from the instructor, rather than active participants and rarely give out their own thoughts about the subject matter. Teachers should make students think deeply about the topic and the value of what they think and feel rather than make students appreciate only what the instructor says. Teachers should teach in such a way that students can believe that their ideas matter. Students should be taught to associate and distinguish patterns. They should experience responsibility for their own education and think about what they have learned and read. Students should be involved with their own learning, feel deeply about 
it, and learn to value and trust their own thoughts and ideas. These techniques will no doubt promote critical thinking in students.

After every class immediate feedback about what knowledge students gained and what they still need to understand should be obtained. This can be done through a simple exercise. At the end of the class students should be given few minutes to jot down on a paper the most noteworthy thing they learned in class each day and state what single thing they still feel confused about. This way their writing too will also improve.

Teachers should encourage students to ask questions in class. Questions from students should always be entertained positively; questioners should never be brushed or belittled. Instead, they should be rewarded by verbal praises. Questions from students mean they are thinking critically about what the teacher said; they should be encouraged. Homework assignments have immeasurable possibilities to promote critical thinking. Assignments are the best and the easiest way of developing both writing as well as critical thinking. Pushing problem students through such writing assignments help develop their own thinking and thought organizational power about a particular lecture on text. This kind of assignments can be initiated by encouraging students to write on easy and interesting topics or an area they fell comfortable in. In class as well as in examinations teachers should set questions which will force students to do brain storming and record their thoughts eventually.

\section{The Necessity of Critical Thinking:}

The objective of teaching critical thinking in the arts and literature or in any other branches of learning is to develop the reasoning skills of students and to prepare them to encounter challenges. Oliver \& Utermohlem (502) see "students as too often being passive receptors of information". A literary lecture at the tertiary level in Bangladesh seems to be a one-way traffic -the teacher is the sole presenter and students are passive listeners who may not even ask a single question. Learners quite often find out that an easy way of analyzing a text is to merely swallow prepared answers or adopt the interpretation given by the teachers themselves without even thinking for an instance to add or include their own assumption or evaluation of the topic. In this context an example may be citied which I often utilize while teaching poetry. Let's take the poem 'My Last Duchess' by Browning. A commonly set question in the exam is 'How do you justify the killing of the Duchess by the Duke?' Almost all students advocate in favor of the cruel Duke 
though there are ample chances to win out the debate if the discussion were thrown in favor of the duchess. Unfortunately, most of the readymade guides advocates in favor of the duke and these sway our students easily. Very few, indeed, it can be said quite a negligible number of students seldom tries to come out of this well-established practice. The reason is a lack of mastery over the target language and the lack of critical thinking. In such situations a language teacher feels helpless. Brown (42) suggests "Development of critical thinking skills in college students is a goal for many college instructors in higher education who seek to prepare their students for postgraduate, realworld situations". The blame may be attributed to their previous orientation of language in the students' secondary and higher secondary class where memorization was stressed over creativity. But as Lipman asserts, "Development of student critical thinking skills is dependent on many variables, including the learning environment, the social context of learning, and the teaching style of the instructor". Even students coming from English medium or overseas sometimes feels baffled in meeting challenge of evaluating and formulating a new and innovative idea, just because of the lack of training in previous years to judge a text from their own point of view. As a result they feel a lack of competence to do so immediately. Thus an instructor can act like a lamppost in encouraging a learner to contradict and to challenge not only the teacher's point of view but also the author's. Through such encouragement learners will discover fact that literature is meant to organize their mental or thinking process in a refined way. Thus this unique means of pedagogy will enable them to translate this kind of meaningful critical awareness beyond the classroom in society as well which in return will make them better social beings having judging and analyzing abilities, and teaching them to discriminate between the good and bad in their day to day journey. Herrington and Oliver (324) believe that "To better prepare for success on the job, students must engage in problem-solving activities that require critical thinking, take place in a social context, and represent an authentic post college work environment". In other words, it will help them to free themselves from being a mere imitator of others' ideas and commands and will allow them to formulate their own understanding and ideas in the most critical situation outside the classroom.

Literature study will not only develop one's imaginative impulse, but can also have a marked influence in the competitive and challenging world of materialism and politics. By analyzing literature critically students will be free of the thought that language learning is not only 
useful in understanding facts and phenomenon already explored in the human world, but also can be a vehicle to add new information and ideas to old ones. This technique of critical analysis will evidently prompt learners to have a say in everything depending on their own value judgment in any situation and making their stay in society a unique one. If this technique is not developed, a language will lose its so-called reputation of being a medium of change, rather, it will prove to be a way of creating an unsound world. Then critical thinking will lend to positive developments.

\section{Interpretation of texts:}

Analytic reading is a key to developing critical thinking. Reading something, critically encourage readers to generate their own value judgment. Our 'primary interest as a teacher is to develop students' reading skills.' (Lazar 181) Learners are sometimes seen losing themselves in their thoughts but soon gain ground. This is the process of thought formation through critical reading. Mere reading cannot benefit a student in critical thinking. The most beneficial way is to tell students to pretend that they are talking to a living person and act, a book. Only then will a learner be benefited in the way of critical thinking. In this case students must be guided by an instructor. Because "Instruction in critical thinking is to be designed to achieve an understanding of the relationship of language to logic, which should lead to the ability to analyze, criticize, and advocate ideas, to reason inductively and deductively and to reach factual or judgemental conclusions based on sound inferences drawn from unambiguous statements of knowledge or belief " (Dumke 28). Critical thinking will grow out of some fixed phenomenon, and teach students to look at a text from various perspectives. Student should be taught to understand the tone of a text at the initial stage. The tone makes it clear whether the piece is sarcastic, or serious. Based on the level of seriousness of the text student will have their say. Next students should look for the objective: didactic, social, political, or mere an artistic one. So as to evaluate the text from that point of view the student should also learn the style of the author: descriptive, narrative, expository, functions etc. Thus knowing about the basic requirements or the elements of a literary piece would enable learners to have a fruitful discussion of the text in light of its, tone, style and objective. Hardcastle (2001) advocates in favour of teaching the following seven critical thinking strategies that may prove helpful for students to think critically: 
a. Annotating: annotating directly on the page: underlining key words, phrases, or sentences; numbering related points in sequence;

b. Previewing: Learning about a text before really reading it.

c. Contextualizing: Placing a text in its historical, biographical, and cultural contexts.

d. Questioning to understand and remember: Asking questions about the content.

e. Reflecting on challenges to your beliefs and values: Examining your personal responses.

f. Outlining and summarizing: Identifying the main ideas and restating them in your own words.

g. Evaluating an argument: Testing the logic of a text as well as its credibility and emotional impact.

h. Comparing and contrasting related readings: Exploring likenesses and differences between texts to understand them better.

The above-mentioned seven critical thinking strategies have been discussed in brief below.

\section{a. Annotating}

Annotating is an important skill to utilize if students desire to develop critically thinking. Successful critical thinkers read with a pencil in their hand, formulating notes in the textbook as they read. Instead of reading inactively, they think keenly, critically forming an effective correlation with what they are reading by taking notes in the margin of the text. With the present text- Ernest Hemingway's "A Clean, WellLighted Place", learners may make the following annotations as they read: They may:

(a) mark the thesis and main points of text. Students should be educated to think robustly on the main focus of the text and establish a connection between pain and old age. Thus they might reach the thesis of "A Clean, Well-Lighted Place" which is on the pain of old age endured by a man that we meet in a cafe late one night.

(b) mark key terms and unfamiliar words ("café", "nada", "insomnia" etc.) 
(c) underline important ideas and memorable images

(d) write questions and comments in the margins of the piece

(e) write any personal experience related to the text

(f) mark confusing parts of the text, that needs a reread

\section{B. Previewing}

Previewing a text means gathering as much information about the text as students can before they actually read it. Teachers can encourage students to relate the following questions to the text.

Who is the author?

What is the purpose for reading a text?

What does the title "A Clean, Well-lighted Place" suggest?

How is the text structured?

Classroom teaching should encourage students to challenge teachers and peers and enable students to think and develop critical ideas about the text from the first glance.

\section{Contextualizing}

Teaching should enable students to place a text in its historical, biographical, and cultural contexts. It's the duty of the classroom teacher to introduce students to the many things that account for the rural or small town Spanish characters and scenery of Hemingway's "A Clean, Well-Lighted Place." Student should be informed that as an emigrant artist living on the continent in the 1920s, Hemingway was obsessed with things of Spain. He was an all-time admirer of Spanish popular traditions. He enjoyed festivals, and was devoted to bullfights. He often went to Spain to fish in the countryside, and so he came to know its people. In addition to this acquaintance with Spain's 'plain folk' (e.g. waiters in small towns) Hemingway scrupulously wishes to avoid in his art anything resonant of "civilization".

\section{Questioning to understand and remember}

Teachers should create an environment in the class to induce students to inquiry and to help them understand what is being read. Students can respond critically to a text by writing a response in their notebook or by discussing the text with others. Once students have understood the author's ideas objectively, they can respond to them in their notebook. They can agree or disagree with the text, interpret it, or 
analyze it. Working with a text by responding in these ways is a good way to develop critical thinking.

\section{E. Reflecting on challenges to your beliefs and values}

Cooperative activities are significant in developing critical perceptions. Sharing knowledge of a text with others reading the same text is a helpful way of checking student understanding and opens up new possibility of interpretation. They should be pushed to annotate a text on their own first, and then discuss with a group of classmates about how they have annotated their texts. This participation in class discussion of a shared text, and expressing students' ideas about a text, will encourage them to think about a text critically.

\section{F. Outlining and summarizing}

Students' creative and critical faculty will develop if they are given the chance to encapsulate the main idea Hemingway portrays in his fiction. Summarizing the text is a helpful way of encouraging understanding of the text by the students. Students should be taught the way of winding up the text by introducing them to its thesis because it is the main idea or claim of the text. Here students will need all kind of support from the teacher because sometimes the thesis is not explicitly stated, but is implied in the text. Only, with help and encouragement from the classroom teacher will learners be able to discover the overall idea the author is interested in exploring in the text.

\section{G. Evaluating an argument}

Analyzing a text means breaking it down into its parts to find out how these parts relate to one another. Through logical argument teacher may alert students to the functions of various parts of Hemingway's fiction and help them safe their relationship to one another and arrive at the overall evaluation of "A Clean, Well-lighted Place".

\section{H. Comparing and contrasting related readings}

Comparing and contrasting related reading materials helps to develop the insight of the learners. Teachers in the class may draw students' attention to dates and events like 1920, 1930, WWI, WWII etc. to stress out students' creativity and thinking. Teachers may analyze and compare texts that express a universal theme, and locate support in the text for the identified theme to the students during their lectures. In such cases "The Love Song of J. Alfred Prufrock" "The Glass Menagerie" "Death of a Salesman" may be compared and contrasted to "A Clean, Well-Lighted Place." 


\section{Mechanisms to help improve critical reading and thinking:}

Students usually are not ready to take risk or become fool before their peers by exposing their own ideas, thoughts and thinking while evaluating a piece of literature. But the objective of teaching literature in a classroom is to enhance the critical and psychological development of a student. "The teaching methods employed must give students exposure to experts' strategies by coaching, providing scaffolding, then fading - gradually handing over the control of the learning process" (Berryman 68). To bring this into practice a teacher can present chunks of literature to students and compel them to think critically over it. This might take the form of interpretation, inference, analysis and argumentation.

The story we are going to analyze as a test case for teaching critical thinking is the American short story- "A Clean, Well-Lighted Place" by Hemingway. This literary piece has been selected because it consists of significant thinking material for readers in terms of the elements of fiction.

"A Clean, Well-Lighted Place" is set in motion with the description of a lonely café at early evening. Two waiters work in the café - one a young man and the other an old one. Another old man, hard of hearing, is a regular customer and visits the café at the same time every evening and stays there till midnight. The younger of the two waiters, become really tired of serving the old man till late as his wife was waiting for him at home. The details about the old man are exposed through the conversation of the two waiters. A detailed model analysis of the text which may be carried out in a class may be as follows.

\section{A. Subject matter:}

The subject of "A Clean, Well-Lighted Place" is a frustrated old man who tries to give good reason for life in a world which for him is quite vacant. To excite students' critical faculty a vital question that may be asked is -'How can you mirror the character in a critical analysis in "A Clean Well-Lighted Place"? In response to such a question students may develop a habit of comparing and contrasting contrary things, ideas or characters. In such cases many students may come back with intellectual answers such as the following: Hemingway's short story is a notable story about contrasts between youth and age, belief and doubt, light and darkness. To the younger waiter, the café is only a job; to the older waiter, it is a charitable institution for which he feels personal responsibility. In exploring such critical and vital ideas students will 
ponder deeply on the young waiters comment about the old customer and old age when he says - "an old man is a nasty thing. (ACLWP-10)". This and other such points will help students to think critically.

\section{B. Significance of the title:}

In capturing the meaning of any text understanding of the tile is important. That is why it will be a good drill for students to let them think and find out the significance of the title. In Hemingway's brief but intense title "A Clean Well-lighted Place", solidarity is found in physical objects-the bar, the drink, routined life, and the presence of others. The very title of Hemingway's short story "A Clean, WellLighted Place" clearly suggests that the story under study will present an intensely poetic description and force the reader to see mankind's never-ending yearning to find spiritual peace. Hemingway's short story exhibits this emotional journey in many different ways. First, the title itself is a symbol for man's desire to find a state of tranquility, safety, and comfort. Hemingway also demonstrated this idea in the story's setting, which was used as a symbol for a sense of order, for it, was late, the cafe was empty, and the men there were at ease. Finally, Hemingway showed this desire in the contrasting actions between the young and the old to show the effects that time plays in man's search for peace. If the students are asked to evaluate the significance of the title they will try to look at the life of old people in their own country in comparison to that of the one in the text. This way they will come to feel the plight of old people and will acquire an insight into old age as well. They might come up with the conclusion that the hollowness revealed the old man's consciousness is an existential one: he feels a gap at the core of his psyche, and realizes how incomprehensible the meaning of life and the nature of existence is.

\section{Plot:}

How is the story's plot advanced? If students are given such an interesting and subtle question, they will totally be at a loss. After all, there is almost no plot per se in this story; one could plausibly say, "Not at all," and just stop there. However, if we define plot more broadly, the plot is advanced considerably by the dialogue. The dialogue tells us about the characters, and, more importantly for the plot, it provides the emotional momentum that carries the older waiter into that final explosion of despair which defines the story and gives it its meaning. The dialogue creates pressure by a back-and-forth movement, and it introduces symbolic elements (light, darkness, age, fear), all of which are essential for that eruption of private despair. If 
students are once trained to look at a text in this way, they will no doubt be able to profit beneficial output by reading a text of this kind.

\section{Character analysis:}

Another very important and vital question that can be asked is about the protagonist or the central character. Such a question no doubt can stimulate students into a debate about whether the old man, the old waiter or the young waiter in the story is more likely to be seen as the central character. Now to establish their view point students have to use logic and that will no doubt stimulate their thinking power. In doing so they will try to compare and contrast the characters of the story with characters they have so far encountered in their lives.

\section{E. Inference:}

Analysis teaches students what to look for and inference teaches then how to think about what they find and relate facts to one another in a logical and coherent way. Analysis is important because through it students learn which aspects of the text control meaning. Through inference students learn how to interpret the data which they recognize through their analysis. One such analysis or inference students might encounter in the story is as follows is: "Why is the cafe considered to be clean and well-lighted?" Hemingway in his story time and again displays a kind of fear or insecurity. Man has an inner fear or a feeling of anxiety that he may never find the peace that he is searching for. Many of us wander through life searching, longing, and seeking for a place or state of being where we will feel comfortable. Many of us long for a safe haven or "A Clean, Well-Lighted Place." This kind of inquiry may persuade students to think more intensely, this in turn, will develop them as critical thinkers.

\section{F. Argumentation:}

The word 'argument' suggests a negative meaning most of the time suggesting disagreement with others. But this is not the case all the time; rather, it is an exploration of facts and beliefs about a particular thing. It is a faculty to be cultivated through practice. Students should be taught to think and argue logically both in the verbal and written form. Critical thinking ability can be developed through a logical and coherent argument. In "A Clean, Well-Lighted Place" the "nada" philosophy seems to even challenge god's existence. Is Hemingway in any way suggesting the hollowness of life or does he want to say that god is dead to the modern world? From Hemingway's argument student may immediately start exploring the various beliefs prevailing 
around them and come to understand God's existence clearly from their explorations.

\section{G. Tone:}

To know the purpose of the text, we must have a clear idea of the tone of the text. The tone might be sarcastic, melodramatic, subtle and ironical, austere or harsh. In developing their critical thinking, students might be asked: what is the tone and the atmosphere of Hemingway's story? The students may say the tone is austere; it is created by the minimalist style- the use of simple economical forms and structures, the point of view, by the brevity and tight focus, all which of course is quite true. The atmosphere might be seen as one of dignified despair; there is no real hope or alternatives, but still the characters keep on living their respective lives expecting that something from life. Credit should be given to students for such critical and analytic answers.

\section{H. Setting:}

The setting of "A Clean, Well-Lighted Place," conveys the whole message of the author. If we compare the two old characters in the story with the young one, we will see that the café is a safe refuge for the old. The café is well-lighted and neat representing heaven to lonely persons devoid of friend and family. Here a person can regain dignity and get what he misses at home only because he is old and cannot contribute to family and society any more. Doing such analysis of the text will of course develop the cognitive power of the students and help them cope with the critical situations of life.

\section{Conclusion}

The sole aim of this study is to propose ways and means of forcing students to think critically rather than just memorizing or parroting the prepared materials in order to pass examinations or please teachers in a classroom situation. So according to Johnson (110) "Write, read, and speak English clearly and effectively in order to acquire knowledge, convey and discuss ideas, evaluate information, and think critically." The paper suggests and proposes guidelines a teacher might find useful in preparing lesson plans or lessons for the students. Teachers can get more help through further training and by attending seminars, symposiums and taking assistance from seniors in this regard. Success in making students think critically is not an easy task for an individual teacher. Here teachers, students and even administrators will have to work hand in hand to prop-up each other. 


\section{References:}

All references and discussions from Hemingway's story are from Kennedy, X.J. Gioia, Dana. (2002). "A Clean Well-Lighted Place". Literature: An Introduction to Fiction, Poetry, and Drama, $3^{\text {rd }}$ compact Ed. London: Longman.

Berryman, S. E. (1991). Designing effective learning environments: Cognitive apprenticeship models. p-68. Source -Internet ERIC Identifier - 337689

Beyth-Marom, R.; Novik, R.; and Sloan, M. (1987). "Enhancing Children's Thinking Skills: An Instructional Model for Decision-Making Under Certainty." Instructional Science 16/3: 215-231.

Browne MN et. al., (1988). 'Do college students know how to "think critically" when they graduate?' Research Serving Teaching 1(9): Spring, p-42 Source Internet ERIC Identifier - ED298442

Brumfit, C, J. and. R.A Carter. (Eds.) (1986). Literature and Language Teaching, Oxford: OUP.

Dumke, G. (1980). "Chancellor's Executive Order 338, California State University” Long Beach: Chancellor's Office. p-28

Facione, Noreen C. (1995)."Critical thinking and clinical judgment: Goals 2000 for nursing science." A paper presented at the Annual Meeting of the Western Institute of Nursing. San Diego, California. p-10

Gough, D. (1991). Thinking About Thinking, Alexandria: VA: National Association of Elementary School Principals. p-99-100. Source -Internet ERIC Identifier - ED327980

Hardcastle, V. Gray: (1995)."Critical Reading Strategies," [Online document], 1995 July 8, [cited 2001 July 30], Available HTTP: http://mind.phil.vt.edu/www/1204crs.html

Herrington J and Oliver R (1999): 'Using situated learning and multimedia to investigate higher-order thinking' J Interactive Learning Research 10: p-3-24.

Johnson, Betty M.. (1986) Essentials of College and University Education for Professional Nursing: Final Report. Washington, D. C.: American Association of Colleges of Nursing. p-110

Jones, E. A. \& Ratcliff, G. (1993). Critical Thinking Skills for College Students. National Center on Postsecondary Teaching, Learning, and Assessment, PA: University Park, p-642. Source -Internet ERIC Identifier - ED358772

Kagnarith, Chea et. al. (2007) 'A Questionnaire Project; Integrating the Four Macro Skills with Critical Thinking, English teaching Forum, vol. 45, Washington DC 20547: US Dept. of STE, p-03

Lazar, Gillian (2002). 'Literature and Self-access', Literature and Language Teaching, Cambridge: Cambridge University Press.

Lipman M. (1991). Thinking in Education. Cambridge, UK: Cambridge University Press, 1991.

Oliver, H. \& Utermohlen, R. (1995). “An innovative teaching strategy: Using critical thinking to give students a guide to the future". p-502 Source -Internet ERIC Identifier - ED389702

Scriven, M. \& Paul, R. (1996). Defining critical thinking: A draft statement for the National Council for Excellence in Critical Thinking. [On-line]. Available HTTP: http: // www.criticalthinking.org /University /univlibrary / library.nclk p-01 